\title{
FIRST RECORD OF A LESSEPSIAN MIGRANT, POMADASYS STRIDENS (ACTINOPTERYGII: PERCIFORMES: HAEMULIDAE), FROM THE AEGEAN SEA, TURKEY
}

\author{
Okan AKYOL* and Vahdet ÜNAL \\ Ege University Faculty of Fisheries, Urla, Izmir, Turkey
}

\begin{abstract}
Akyol O., Ünal V. 2016. First record of a Lessepsian migrant, Pomadasys stridens (Actinopterygii:
Perciformes: Haemulidae), from the Aegean Sea, Turkey. Acta Ichthyol. Piscat. 46 (1): 53-55.
\end{abstract}

\begin{abstract}
A new record of a Lessepsian migrant, the striped piggy, Pomadasys stridens (Forsskål, 1775), in Turkish waters is reported herewith. The specimen was captured off the Akyaka coast in Gökova Bay, SE Aegean Sea and measured $130 \mathrm{~mm}$ in total length. Other measurements and counts are also provided, as well as the list of other Mediterranean records. This finding constitutes the fist record of this fish from the Aegean Sea and the third record from Turkish marine waters. It is also the northernmost report of this species in the Eastern Mediterranean Sea.
\end{abstract}

Keywords: new record, extension range, measurement, Mediterranean

The family of Haemulidae accommodates 133 species. In this number there are four species native to the Mediterranean (Froese and Pauly 2016). The only Mediterranean non-native species of this family is the striped piggy, Pomadasys stridens (Forsskål, 1775).

Pomadasys stridens inhabits coastal waters and swims in schools over sandy substrates to a maximum depth of $25 \mathrm{~m}$ (Golani et al. 2006, Froese and Pauly 2015). It feeds on crustaceans and fish (Froese and Pauly 2016). Reproduction occurs in the summer months, and eggs and larvae are planktonic (Ben-Tuvia and McKay 1986, Golani et al. 2002).

Pomadasys stridens is known from the Indian Ocean where it has been recorded from: Red Sea, off South Africa, off Western India, and from East Africa (from Mozambique to the Arabian Gulf ) (Golani et al. 2002, Froese and Pauly 2016). It is very likely that the fish entered the Mediterranean from the Red Sea via the Suez Canal and its known records stretch from Egypt (Golani et al. 2006) to the Gulf of Iskenderun, Turkey (Bilecenoglu et al. 2009).
In the Mediterranean Sea, Pomadasys stridens was recorded for the first time from the Gulf of Genoa, Italy by Torchio in 1969 (Golani et al. 2002). It was later found in Bardawil Lagoon (Northern Sinai, Egypt) by BenTuvia (1976). Golani (1998) reported that P. stridens occurred between Egypt and Lebanon in the south-eastern Mediterranean coasts. More recent records were given in Table 1 .

On 3 November 2015, one specimen of Pomadasys stridens (Fig. 1) was captured by a trammel net $(56 \mathrm{~mm}$ stretched mesh size) from Gökova Bay, SE Aegean Sea $\left(37^{\circ} 02^{\prime} \mathrm{N}, 28^{\circ} 18^{\prime} \mathrm{E}\right)$ at a depth of $30 \mathrm{~m}$. The specimen was fixed in 5\% formaldehyde solution and stored in the fish collection of the Ege University, Fisheries Faculty (ESFM-PIS/2015-07).

The specimen was measured to the nearest $1 \mathrm{~mm}$ (Table 2). Brief description of the specimen: body oblong and compressed with small ctenoid scales; colour silvery with three golden longitudinal stripes on upper half of body; pronounced dark spot on upper corner of opercle. All presently determined measurements, and colour patterns

Table 1

Recent records of Pomadasys stridens in the Mediterranean Sea

\begin{tabular}{lcccccl}
\hline \multicolumn{1}{c}{ Location } & Coordinates & Depth [m] & Record Date & $\begin{array}{c}\text { Number } \\
\text { collected }\end{array}$ & $\begin{array}{c}\text { Size, TL } \\
{[\mathrm{mm}]}\end{array}$ & Reference \\
\hline Yumurtalik, Turkey & $36^{\circ} 49^{\prime}, 35^{\circ} 54^{\prime}$ & 20 & 18 Oct 2009 & 6 & $133-158$ & Bilecenoglu et al. 2009 \\
Coasts of Israel & $31^{\circ} 43^{\prime}, 33^{\circ} 05^{\prime}$ & $15-270$ & $2008-2011$ & 18 & $69-145$ & Edelist 2014 \\
Iskenderun, Turkey & $36^{\circ} 04^{\prime}, 36^{\circ} 32^{\prime}$ & - & $2011-2012$ & 335 & $76-177$ & Erguden et al. 2015 \\
Cape Greco, Cyprus & $34^{\circ} 57^{\prime}, 34^{\circ} 05^{\prime}$ & 20 & 20 Sep 2014 & 1 & 149 & Iglésias and Frotté 2015 \\
Gökova Bay, Turkey & $37^{\circ} 02^{\prime}, 28^{\circ} 18^{\prime}$ & 30 & 03 Nov 2015 & 1 & 130 & Presently reported study \\
\hline
\end{tabular}

* Correspondence: Dr Okan Akyol, Ege Üniversitesi, Su Ürünleri Fakültesi, 35440 Urla, Izmir, Turkey, phone: (+90) 2327521162, fax: (+90) 2323747450, e-mail: (OA) okan.akyol@ege.edu.tr, (VÜ) vahdetunal@gmail.com. 


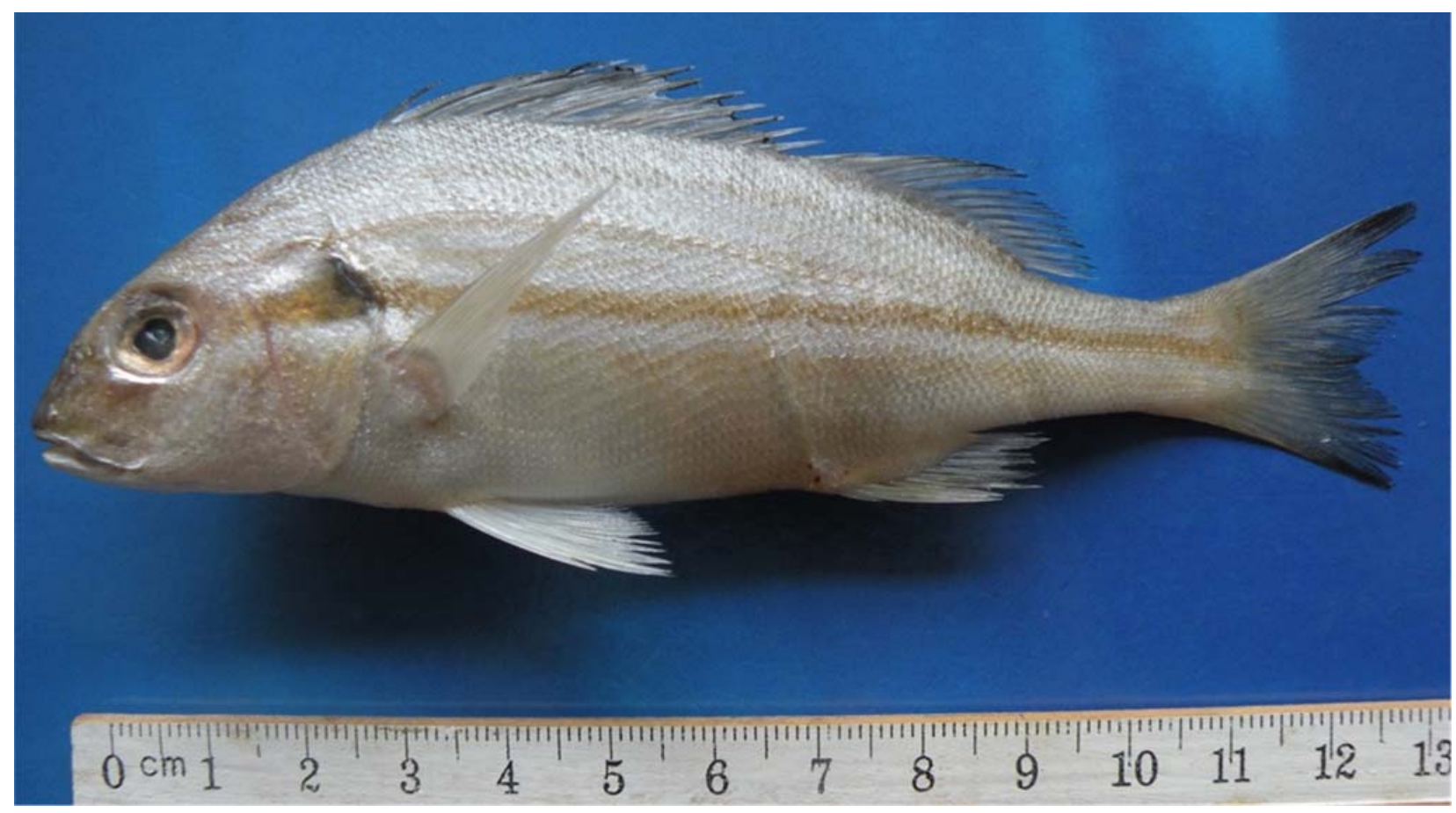

Fig. 1. Pomadasys stridens, caught from Gökova Bay, SE Aegean Sea (ESFM-PIS/2015-07), Photograph by O. Akyol

Table 2 indicates a successful establishment of this fish along the Morphometric and meristic characters of the specimen of Eastern Mediterranean coasts. However, one specimen Pomadasys stridens, (ESFM-PIS/2015-07) captured in Gökova Bay, SE Aegean Sea, Turkey

\begin{tabular}{lrcc}
\hline \multicolumn{1}{c}{ Character } & \multicolumn{2}{c}{ Size } & Count \\
\cline { 2 - 3 } & {$[\mathrm{mm}]$} & {$[\%$ of $]$} & \\
\hline Total length (TL) & 130 & & \\
Fork length (FL) & 123 & $94.6 \mathrm{TL}$ & \\
Standard length (SL) & 111 & $85.4 \mathrm{TL}$ & \\
Maximum body depth & 35 & $26.9 \mathrm{TL}$ & \\
Predorsal fin length & 39 & $30.0 \mathrm{TL}$ & \\
Prepectoral fin length & 34 & $26.2 \mathrm{TL}$ & \\
Preanal fin length & 68 & $52.3 \mathrm{TL}$ & \\
Head length (HL) & 33 & $25.4 \mathrm{TL}$ & \\
Eye diameter & 9 & $6.9 \mathrm{TL}$ & \\
Preorbitary length & 10 & $30.3 \mathrm{HL}$ & \\
1st dorsal fin rays & & & XII \\
2nd dorsal fin rays & & & 13 \\
Anal fin rays & & & III +8 \\
Pectoral fin rays & & & 16 \\
Ventral fin rays & & & $\mathrm{I}+5$ \\
\hline
\end{tabular}

are in accordance with the descriptions of Ben-Tuvia and McKay (1986), Golani et al. (2002, 2006), Bilecenoglu et al. (2009), and Froese and Pauly (2016).

The presently reported finding constitutes the fist record of this fish from the Aegean Sea and the third record from Turkish marine waters. It also represents the northernmost record of this species in the Eastern Mediterranean.

The presence of recently recorded 361 specimens of Pomadasys stridens in different localities and years (i.e., Iskenderun, Yumurtalık, and Israel coasts) (Table 1) found in Cape Greco, Cyprus and the presently reported new record also indicate that $P$. stridens has been advancing westward step by step.

\section{REFERENCES}

Ben-Tuvia A. 1976. Occurrence of Red Sea fishes Herklotsichthys punctatus, Autisthes puta and Rhonciscus stridens in the eastern Mediterranean. Israel Journal of Zoology 25: 212-213.

Ben-Tuvia A., McKay R. 1986. Haemulidae. Pp. 858864. In: Whitehead P.J.P., Bauchot M.-L., Hureau J.-C., Nielsen J., Tortonese E. (eds.) Fishes of the north-eastern Atlantic and the Mediterranean. Vol. 2. Unesco, Paris.

Bilecenoglu M., Kaya M., Eryigit A. 2009. New data on the occurrence of two alien fishes, Pisodonophis semicinctus and Pomadasys stridens, from the Eastern Mediterranean Sea. Mediterranean Marine Science 10 (2): 151-155. DOI: $10.12681 / \mathrm{mms} .117$

Edelist D. 2014. New length-weight relationships and $\mathrm{L}_{\max }$ values for fishes from the southeastern Mediterranean Sea. Journal of Applied Ichthyology 30 (3): 521-526. DOI: $10.1111 /$ j.1439-0426.2012.02060.x

Erguden D., Erguden S.A., Gurlek M. 2015. Lengthweight relationships for six fish species in Iskenderun Bay (eastern Mediterranean Sea coast of Turkey). Journal of Applied Ichthyology 31 (6): 1148-1149. DOI: $10.1111 /$ jai.12839

Froese R., Pauly D. (eds.) 2016. FishBase. [Version 01/2016] www.fishbase.org 
Golani D. 1998. Distribution of Lessepsian migrant fish in the Mediterranean. Italian Journal of Zoology 65 (Suppl. 1): 95-99. DOI: $10.1080 / 11250009809386801$

Golani D., Orsi-Relini L., Massuti E., Quignard J.P. 2002. CIESM Atlas of exotic species in the Mediterranean. Vol. 1. Fishes. CIESM Publications, Monaco.
Golani D., Özturk B., Başusta N. 2006. Fishes of the eastern Mediterranean. Turkish Marine Research Foundation, Istanbul, Turkey.

Iglésias S.P., Frotté L. 2015. Alien marine fishes in Cyprus: Update and new records. Aquatic Invasions 10 (4): 425-438.

DOI: $10.3391 /$ ai.2015.10.4.06

Received: 13 November 2015 Accepted: 20 March 2016

Published electronically: 31 March 2016 